\title{
Productivity and durability of Heliconiaceae grown under different conditions and stored under refrigeration
}

\begin{abstract}
Heliconia (Heliconiaceae) species are widely commercialized by producers and consumers, due to the beauty and variety of shapes, colors of bracts, resistance to transport, and postharvest durability of their flowers stem. The purpose of this study was to evaluate the productivity and durability of bracts of three species of Heliconia spp., under different conditions of cultivation and cold storage temperatures. Heliconiaceae accessions cultivated in full sun and semi-shade were evaluated for the number of marketable stems produced and their postharvest durability under varying storage temperature conditions $(16,19$, and $26^{\circ} \mathrm{C}$ ). Data from two years of cultivation were subjected to analysis of variance and Scott Knott's test. The productivity of flower stems was influenced by the growth conditions. $H$. psittacorum and $H$. bihai (Maluca) showed higher yields under shaded cultivation, while the highest productivity for $H$. densiflora was observed in full sun cultivation. Temperatures of 16 and $19^{\circ} \mathrm{C}$ effectively prolonged the life of the flower stems. Shaded cultivation and refrigerated storage of Heliconia spp. are important methods to ensure successful cultivation and commercialization of these species, as they increase productivity and extend the useful life of flower stems.
\end{abstract}

Keywords: tropical flowers, postharvest, light intensity, shaded cultivation, refrigerated storage
Volume 4 Issue 4 - 2020

\section{Auclar Felipe Botini, Maria Helena Menezes Cordeiro, Willian Krause, Celice Alexandre Silva}

Graduate Program in Genetics and Plant Breeding, State University of Mato Grosso, Brazil

Correspondence: Celice Alexandre Silva, Graduate Program in Genetics and Plant Breeding, State University of Mato Grosso, MT-358, 7- Jardim Aeroporto, Tangará da Serra, Mato Grosso, Brazil,Email celice@unemat.br

Received: July 25, 2020 | Published: August 10, 2020

\section{Introduction}

As an economically important sector in agribusiness, production of flowers and ornamental plants in Brazil are gaining a prominent position.This sector shows high potential for further expansion, as it provides employment and income for micro and small producers across the country. ${ }^{1}$

Among the tropical flowers grown in Brazil, genus Heliconia (Heliconiaceae) is important to the ornamental plant market. ${ }^{2}$ Heliconiabihai, $H$. psittacorum, $H$. wagneriana, $H$. rostrata, and $H$. stricta are some of the most grown species in Brazil along with cultivars such as, H. psittacorum var. Golden Torch and Red Torch. ${ }^{3}$ Heliconia plants are widely preferred by producers and consumers alikefor their beauty, variety in shapes, colors of bracts, and postharvest durability of flower stems. ${ }^{4}$ However, there is a lack of information regarding development, planting systems, harvest and postharvest management, and the influence of these factors on the quality of these species. ${ }^{5}$ To efficiently produce and market these plants, factors such as choosing the appropriate species and varieties, availability of propagation materials and suitable structures for cultivation (climate control and planting system, fertilizers, and pest and disease management), as well as knowledge of production and postharvest techniques are essential.

The objective of the present study was to evaluate the productivity and durability of Heliconia spp. in semi-shade cultivation and in full sunlight.

\section{Materials and methods}

The experiment was carried out in the experimental area of the University of the State of Mato Grosso (UNEMAT), located in the municipality of Tangará da Serra - MT (" $14^{\circ} 08^{\prime} 38^{\prime}$ " S and " $57^{\circ} 03^{\prime} 45^{\prime}$ "
W). The region has a tropical climate, and is at an altitude of $488 \mathrm{~m}$ with an annual rainfall of $1,830.8 \mathrm{~mm}$. The dry season extends from June to August and the rainy season from October to April ${ }^{7}$.The soil is classified as Dystroferric Red Latosol with clay texture and flat to slightly undulating relief. ${ }^{17}$

The accessions of Heliconia densiflora, Heliconia psittacorum var. Golden Torch, and Heliconia bihai (Maluca) (Figure 1) were cultivated in two cultivation systems, fullsun, and semi-shade $(30 \%)$. The plants were spaced at a distance of $3 \times 3 \mathrm{~m}$ and irrigation through micro-sprinkling, with one microjet per clump.During planting, fertilization in the pit was carried out with $200 \mathrm{~g}$ of formulated N-P-K in the proportion of 3: $1: 2$. During the following years, top dressing with $150 \mathrm{~g}$. pit $^{-1}$ of the formulated N-P-K in the proportion 15:15:15 were carried out every three months. ${ }^{2}$

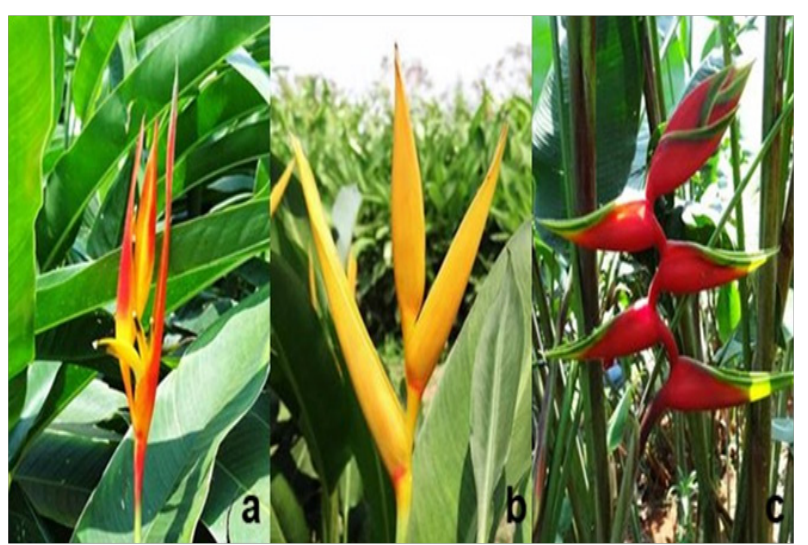

Figure I H. densiflora (a), H. psittacorum var. Golden torch (b), H. bihai (Maluca) (c)in semi-shade cultivation. Tangará da Serra - Brasil, 2017. 
The experimental design was set up in randomized blocks with seven replicates and one clump per plot, in a $3 \times 2 \mathrm{~m}$ factorial scheme (accesses $\times$ environment), to evaluate productivity. Postharvest durability was evaluated in a triple factorial scheme, with three temperatures $\left(16^{\circ} \mathrm{C}, 19 \pm 3{ }^{\circ} \mathrm{C}\right.$, and $\left.26 \pm 3^{\circ} \mathrm{C}\right)$, three accessions, and two cultivation environments. Four replicates of 10 stems per plot were used. A cold chamber was used to store plants under temperatures of $16^{\circ} \mathrm{C}$ and $19 \pm 3{ }^{\circ} \mathrm{C}$ with a relative humidity of $80 \%$. The flower stems were maintained in the laboratory at atemperature of $26 \pm 3^{\circ} \mathrm{C}$ and a relative humidity of $50 \%$.

The flower stems were harvested weekly between 0700 and 0800 , during the two years of production. After harvesting, the flower stems were taken to the postharvest shed where the number of marketable stems was separated by counting the number of stems that had a commercial pattern (flower stem length greater than $80 \mathrm{~cm}$, diameter of 1-3 cm, and devoid of damage). Using the marketable stems data, flower stem productivity was calculated at ha ${ }^{-1}$. year-1.

Postharvest durability was evaluated from the packaging of marketable flower stems in buckets containing clean water and later stored under refrigeration $\left(16^{\circ} \mathrm{C}, 19 \pm 3^{\circ} \mathrm{C}\right.$, and ambient temperature of $26 \pm 3^{\circ} \mathrm{C}$ ), until the point of disposal. Visual assessments were carried out every day, and when the flower had lost its brightness, dark spots appeared on the inflorescence, or when slightly spotted bracts were visible, the flower stem was discarded.

Statistical analysis was performed using the Sisvar ${ }^{\text {( }}$ statistical program. ${ }^{8}$ Data were subjected to analysis of variance and the means compared using Scott-Knott test at 5\% probability.

\section{Results}

The productivity of $H$. densiflora and $H$. psittacorumvar. Golden Torch was influenced by the culture environment (Figure 2). With respect to $H$. densiflora, the highest productivity was observed in full sun cultivation (3753.97 stems.ha ${ }^{-1}$. year ${ }^{-1}$ ) and on average, was $41.20 \%$ higher than that observed in shaded cultivation. In contrast, H. psittacorum var. Golden Torch in semi-shade condition showed higher productivity (5198.41 stems.ha ${ }^{-1}$. year) than that observed under full sun cultivation (was $3023.80{\text { stems. } \text { ha }^{-1} \text {. year }}^{-1}$ ) (Figure 2).

Cultivation environments did not influence the productivity of $H$. bihai (Maluca), which did not show significant differences between productivity under full sun (2658.72 stems. ha- ${ }^{-1}$ year $\left.{ }^{-1}\right)$ and that in semi-shade (3055.55 stems. ha ${ }^{-1}$. year ${ }^{-1}$ ) (Figure 2).

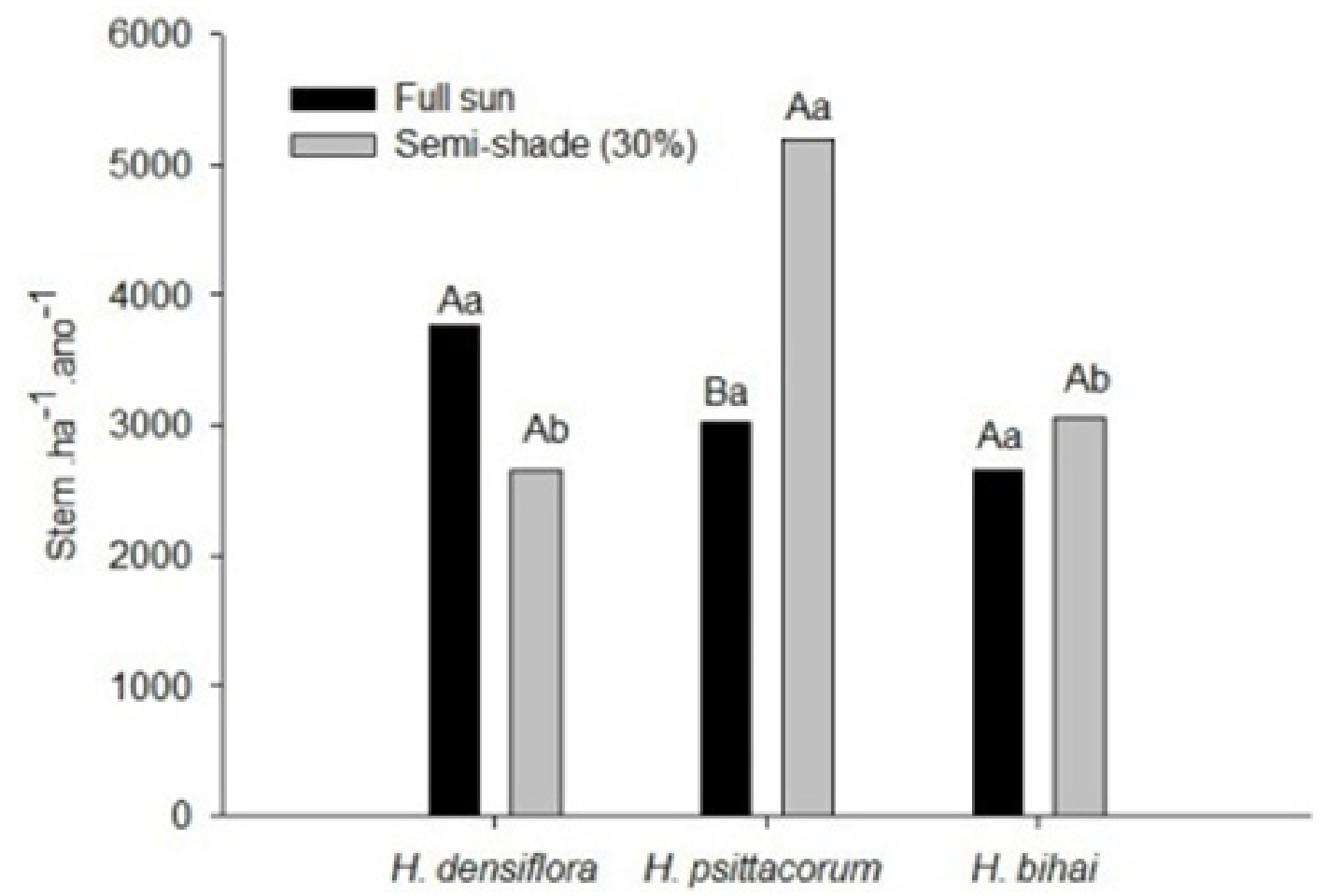

Figure 2 Annual productivity of flower stems of Heliconiadensiflora, H. psittacorum var. Golden Torch, and H. bihai (Maluca) cultivated in full sun and semi-shade (30\%). Uppercase letters compare the cultivation conditions and lowercase letters compare the species evaluated by the Scott-Knott test at $5 \%$ probability. Tangará da Serra - Brazil, 2017.

Under full sun cultivation, no significant differences in terms of productivity were observed between the species evaluated. However, under semi-shade cultivation, H. psittacorum var. Golden Torch stood out from the rest with a productivity of 5198.41 stems. ha-1. year ${ }^{-1}$.

Postharvest durability differed significantly between species and storage temperatures; however, with respect to the cultivation environments, no significant differences were observed by analysis of variance. The temperature of $16^{\circ} \mathrm{C}$ provided durability posthaverst of 17 days for the specie $H$. bihai (Maluca) and differing significantly from $H$. densiflora and $H$. psittacorum that had durability of 14 days (Figure 3). Ats temperatures of 19 and $26^{\circ} \mathrm{C}$, no significant differences were observed to postharvest durability between species. The general postharvest durability average of flower stems at these temperatures was 11.57 and 6.27 days, respectively.

Symptoms of physiological disturbances caused by cold (chilling) during storage at temperatures 16 and $19{ }^{\circ} \mathrm{C}$ were not observed. The 
flower stems, regardless of the storage temperature, showed bracts with loss of luster and turgidity and brown spots on the extremities at the time of discard.

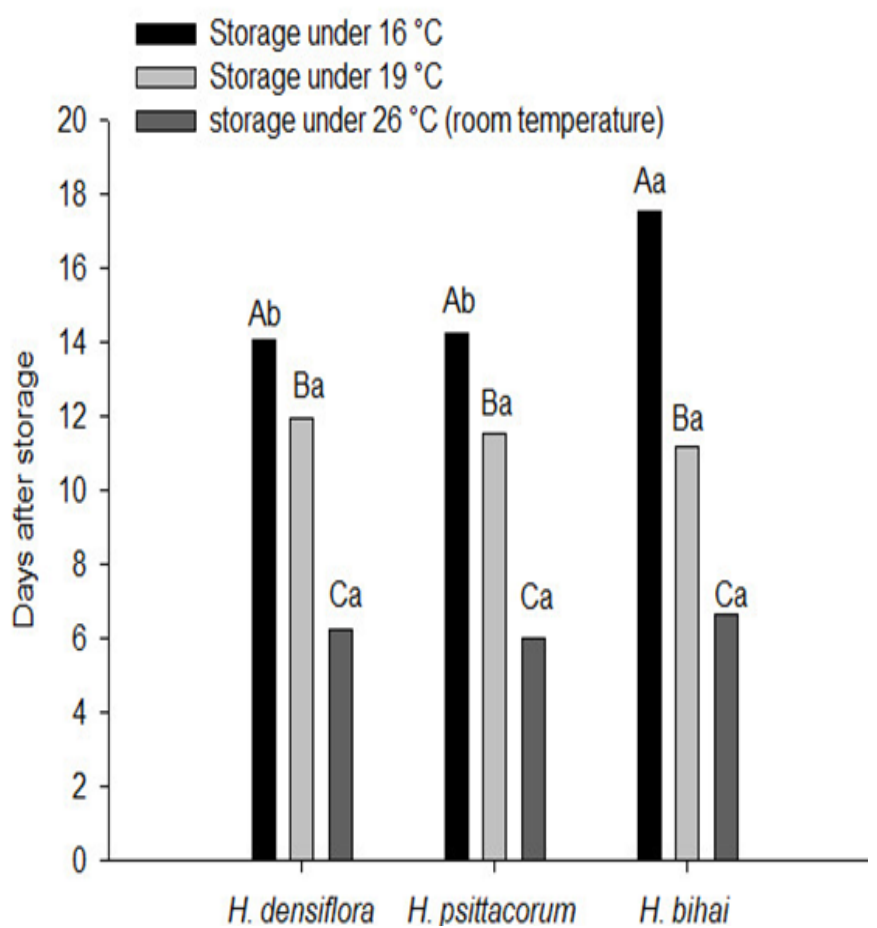

Figure 3 Days of storage of flower stems of Heliconiadensiflora, H. psittacorumvar. Golden Torch, and $\mathrm{H}$. bihai (Maluca) stored at temperatures of 16 and $19^{\circ} \mathrm{C}$ in a cold chamber and $26^{\circ} \mathrm{C}$ in an ambient condition. Uppercase letters compare the species evaluated and lowercase letters the storage temperatures by the Scott Knott test at 5\% probability. Tangará da Serra - Brazil, 2017.

\section{Discussion}

Cultivation environment influences the productivity of Heliconia spp. In general, commercially viable flower stems are usually obtained from shaded crops. Crops grown under shade show intense colors and less damage than is caused by cultivation by direct sunlight. Under full sun cultivation in certain regions of the country, such as in the northern coast of the State of São Paulo and Pernambuco, the stems may show burns on bracts and reduces the number of marketable stems. ${ }^{3}$

In literature, it is reported that under shading conditions of approximately $36 \%$, H. psittacorumvar. Golden Torch shows higher flower stem productivity. ${ }^{9}$ This result corroborates with findings of the present study, where under a shading of $30 \%$, the productivity was almost twice as much as that observed in full sun cultivation.

Although no significant difference was observed, the productivity of $H$. densiflora under cultivation in full sun was higher than that observed in semi-shade environment, which may suggest that the direct light intensity results in a higher flower stem productivity for these species, due to an increased photosynthetic activity.

The postharvest durability of small heliconia, such as $H$. densiflora and $H$. psittacorum var. Golden Torch, is influenced by several factors such as stage of development, harvest time, and postharvest storage temperature.$^{10}$ For tropical flowers, the recommended storage temperature varies between 7 and $15{ }^{\circ} \mathrm{C} .{ }^{11}$ Very low temperatures can cause cold injuries (chilling), inducing symptoms such as discoloration of flowers and necrotic lesions on petals and leaves. ${ }^{12}$

Cold storage with temperatures of 16 and $19^{\circ} \mathrm{C}$ prolonged the life of the flower stems when compared to storage at $26^{\circ} \mathrm{C}$. These results corroborate those found in literature, where it was reported that cold storage prolonged the useful life of heliconia. ${ }^{13-15}$ Low temperatures reduce the rate of transpiration, ethylene production, and respiration; factors that influence the senescence of plant organs. ${ }^{16}$

In a previous study, it was reported that $H$. bihai stored at $19{ }^{\circ} \mathrm{C}$ showed a postharvest durability of 14 days. ${ }^{13}$ In the present study, under the same storage temperature, the average durability of the species was found to be 11 days. Addition to the storage temperature, other factors can influence postharvest durability of flower stems, ${ }^{10}$ such as cultivar, harvest stage, and environment conditions during cultivation.

Temperatures as low as $7{ }^{\circ} \mathrm{C}$ can prolong the life of tropical flowers after harvest. ${ }^{11}$ without affecting the quality of the flower stems. In our study, $16^{\circ} \mathrm{C}$ was the most efficient in extending the durability of the flower stems, regardless of the species evaluated.

Determining a storage temperature that prolongs the useful life of these flowers, without causing damage to the final quality of the product is essential for strengthening the productive chain of tropical flowers, as greater durability will enable to market these flowers in distant markets. In this study, we found that under lower temperature $\left(16^{\circ} \mathrm{C}\right)$, the useful life of these flowers was extended by twice the period of those in ambient conditions.

\section{Conclusion}

The productivity of flowering stems of $H$. densiflora, $H$. psittacorum var. Golden Torch, and H. bihai (Maluca) was influenced by the cultivation environment. H. psittacorum var. Golden Torch and H. bihai (Maluca) showed higher yields under shade cultivation, while $H$. densiflora, showed higher productivity under full sun cultivation.

Low temperature storage effectively prolonged the useful life of flower stems of the three species evaluated, and storing flower stems in a temperature of $26^{\circ} \mathrm{C}$ is not recommended due to rapid deterioration of inflorescence. The durability of the flower stems stored at 16 and $19^{\circ} \mathrm{C}$ was 10 days longer than that at $26^{\circ} \mathrm{C}$.

\section{Acknowledgments}

The authors would like to thank the Coordination for the Improvement of Higher Education Personnel (CAPES), National Council for Scientific and Technological Development (CNPq), Foundation for Research Support of the State of Mato Grosso (FAPEMAT), and State University of Mato Grosso (UNEMAT) for their financial support, study grants and provision of infrastructure.

\section{Conflicts of interest}

Authors declare no conflict of interest exists.

\section{References}

1. Junqueira AH, Peetz MS. O setor produtivo de flores e plantas ornamentais do Brasil, no período de 2008 a 2013: atualizações, balanços e perspectivas. Revista Brasileira de Horticultura Ornamental. 2014;20(2):115-120.

2. Lamas AM. Flores: produção, pós-colheita e mercado. Fortaleza: instituto frutal, 2004;109. 
3. Castro CEF, May A, Gonçalves C. Espécies de helicônia como flores de corte. Ornamental Horticulture. 2006;12(2):112-124.

4. Brainer MSCP, Oliveira AAP. Perfil da floricultura no nordeste brasileiro. In: XLIV Congresso da Sober, Fortaleza; 2006.

5. Loges V, Castro ACR, Guimarães WN, et al. Caracterização de hastes de flores tropicais da emissão até a colheita. Ornamental Horticulture. 2008;14(1):91-97.

6. Motos JR. A importância dos materiais de propagação na qualidade das flores e plantas. Campinas: Informativo Ibraflor; 2000

7. Martins JA, Dallacort R, Inoue MH, et al. Probabilidade de precipitação para a microregião de Tangará da Serra, Estado do Mato Grosso. PesquisaAgropecuária Tropical. 2010;40(3):291-296.

8. Ferreira DF. Sisvar: a computer statistical analysis system. Ciência e Agrotecnologia. 2011;35(6):1039-1042.

9. Catley JL, Brooking IR. Temperature and light influence growth and flower production in Heliconia 'Golden Torch'. Hort Science. 1996;31(2):213217.

10. Jaroenkit T, Paull RE. Postharvest handling of heliconia, red ginger, and bird-of-paradise. Horticulture Technology. 2003;13:259-266.
11. Nowak J, Goszczynska MD, Rudnicki RAI. Storage of cut flowers and ornamental plants: present status and future prospects. Postharvest News and Information. 1991;2(4):255-260.

12. Nowak J, Rudnicki RM. Postharvest handling and storage of cut flowers, florist greens and potted plants. 1st. ed. Portland: Timber Press; 1990.

13. Costa AS, Nogueira LC, Santos VF, et al. Storage of cut heliconia bihai (L.) cv. Lobster Claw flowers at low temperatures. Revista Brasileira de Engenharia Agrícola e Ambiental. 2011;15(9):966-972.

14. Criley RA. Production of heliconia as cut flowers and their potential as new potted plants. Horticulture Digest University of Hawaii. 1990;92:1-6.

15. Broschat TK, Donselman HM. Production and postharvest culture of Heliconia psittacorum flowers in South Florida. Proceedings of Florida State Horticultural Society. 1983;96:272-273.

16. Chitarra MIF,Chitarra AB. Pós-colheita de frutos e hortaliças: fisiologia e manuseio. 2nd ed. Lavras: UFLA; 2005.

17. Santos HG, Jacomine PKT, Anjos LHC, et al. Brazilian system of soil classification. 5th ed. Brasilia, DF: Embrapa; 2018. 